\title{
AVALIAÇÃO DO RENDIMENTO DE CARCAÇA DE CODORNAS PARA CORTE ALIMENTADAS COM DIETAS COM DIFERENTES NÍVEIS PROTÉICOS
}

\author{
(Evaluation of carcass yield of meat from quails fed diets with different protein levels)
}

\author{
OLIVEIRA, E.G. ${ }^{1}$; ALMEIDA, M.I.M. ${ }^{2}$; MENDES, A.A. ${ }^{3}$; VEIGA, N. ${ }^{3}$; ROÇA, R.O. ${ }^{3}$; DIAS, K. ${ }^{4}$
}

'Deptํㅡㄴotecnia, SCA, UFPR, Curitiba ego@ufpr.br; ${ }^{2}$ Dept $\cong$ Genética, SCB, UFPR, Curitiba;

${ }^{3}$ Dept $^{\circ}$ Produção e Exploração Animal, FMVZ, UNESP, Botucatu;

${ }^{4}$ Doutoranda em Genética UNESP, Araçatuba.

\begin{abstract}
RESUMO - Utilizaram-se 960 codornas, distribuídas num delineamento inteiramente aleatorizado com esquema fatorial de 2 sexos $\times 4$ níveis de proteína bruta (PB), sendo as dietas isocalóricas e isolisínicas, num total de 8 tratamentos com 4 repetições de 30 aves cada, para avaliar o rendimento de carcaça de codornas para corte, machos e fêmeas, alimentadas com rações contendo 20\%, 22\%, 24\% e 26\% PB, de 1 a 49 dias. Os níveis de proteína bruta não afetaram significativamente a maioria das variáveis estudadas. Os pesos vivo e de carcaça e o rendimento de vísceras não comestíveis foram superiores nas fêmeas; o rendimentos de carcaça e o rendimento resfriado foram superiores nos machos $(p<0,05)$. Houve interação $(p<0,05)$ para $o$ rendimento de vísceras comestíveis, sendo o rendimento de fêmeas alimentadas com $22 \% \mathrm{~PB}$ superior ao das alimentadas com $24 \%$; não houve efeito do nível protéico sobre o rendimento de vísceras comestíveis de machos.
\end{abstract}

Palavras-chave: carcaça, codornas de corte, proteína bruta, rendimento.

ABSTRACT-An experiment has been carried out aiming to evaluate the carcass yield of male and female meat quails fed with diets containing $20,22,24$, and $26 \%$ of crude protein (CP), respectively, all of them displaying the same caloric and lysine levels. A total of 960 quails were used in a completely randomized design, with a factorial of 2 genders and 4 levels of CP, totalizing 8 treatments with 4 replicates of 30 birds each. Carcass yield was evaluated at the end of 49 days of the beginning of the experiment. The levels of CP used in this trial did not display any significant effect on most of the studied parameters. It has been observed an interaction $(p<0.05)$ for the yield of edible viscera, with females fed with $22 \%$ CP displaying higher averages than those fed with $24 \%$ CP. There was no effect on the protein levels upon males. Body and carcass weights and non-edible viscera yield were higher in females, while carcass and post chilling yields were higher in males $(P<0.05)$.

Key-words: carcass yield, crude protein, meat quail.

\section{Introdução}

A codorna é uma excelente alternativa para a alimentação humana, pois pode ser utilizada tanto para a produção de ovos como para a produção de carne, que é aceita universalmente por ser um produto de excelente qualidade e rica em aminoácidos essenciais, superior até a outras aves como o frango, a perdiz e o faisão (TABOADA, 1998).

A determinação das corretas exigências nutricionais é de grande importância para todas as espécies avícolas, uma vez que a dieta é, talvez, o principal fator ambiental que determina se as aves vão crescer até ao seu potencial genético máximo (MARKS, 1993). Nas codornas de corte este aspecto assume uma importância ainda maior pois de 1 a 28 dias de vida têm o seu peso aumentado em cerca de 16 vezes (OLIVEIRA et al., 2002). A maioria das informações disponíveis sobre os requerimentos nutricionais de codornas de corte são obtidas de literatura estrangeira, em condições totalmente diversas das vigentes no Brasil, o que pode determinar exigências nutricionais diferentes (RAJINI e NARAHARI, 1998; SHRIVASTAV e PANDA, 1999; OLIVEIRA et al., 2000).

Apesar de SHRIVASTAV e PANDA (1999) terem ressaltado a importância decisiva da qualidade da proteína, em detrimento do nível de proteína, este último não deve ser menosprezado pois diversas pesquisas apontam o seu efeito sobre o ganho de peso, a conversão alimentar e a mortalidade, principalmente nas primeiras fases de vida (PANDA e SHRIVASTAV, 1978; DARDEN e MARKS, 1988; RAJINI e NARAHARI, 1998; OLIVEIRA et al., 2000). RAJINI e NARAHARI (1998) ressaltaram ainda a influência do teor de proteína bruta da dieta sobre o rendimento de carcaça, demonstrando que dietas de alta proteína, principalmente se associadas a um baixo nível de energia metabolizável, favorecem a menor deposição de gordura na carcaça, melhorando, consequentemente, o rendimento.

Diante da relevância deste aspecto, os objetivos do presente trabalho foram avaliar o rendimento de carcaça no abate aos 49 dias de codornas para corte de ambos os sexos, alimentadas com rações contendo $20 \%, 22 \%, 24 \%$ e $26 \%$ de proteína bruta. 


\section{Materiais e Métodos}

Este experimento foi conduzido no Setor de Animais Silvestres da Fazenda Experimental Lageado, da Faculdade de Medicina Veterinária e Zootecnia UNESP, campus de Botucatu. Empregaram-se 960 codornas, adquiridas com um dia de idade da Granja Molino Blanco, localizada no município de São Lourenço da Serra, SP, na proporção de $50 \%$ de cada sexo. As aves foram transportadas em caixas apropriadas de papelão até às instalações onde se desenvolveu a fase experimental. Foi utilizado um galpão semi fechado, de $8,00 \mathrm{~m}$ de largura por $11,00 \mathrm{~m}$ de comprimento, com pé direito de $4,00 \mathrm{~m}$, coberto com telha de argila e provido de cortinas plásticas, subdividido internamente em boxes construídos com placas de cimento medindo $1,00 \mathrm{~m}$ de largura $\times 1,00$ $\mathrm{m}$ de comprimento $\times 1,20 \mathrm{~m}$ de altura, cujas partes superior e frontal foram fechadas com tampas removíveis de eucatex ${ }^{\circledR}$ e tela de arame, de modo a permitir a observação das aves.

Os pintos de um dia foram sorteados aleatoriamente para cada um dos oito tratamentos previamente definidos, de acordo com um esquema fatorial de 2 sexos $x 4$ níveis protéicos, num delineamento inteiramente casualizado, com 4 repetições, totalizando 32 boxes. Foram alojadas 30 aves por box.

Até aos 15 dias foram utilizados comedouros do tipo bandeja e bebedouros do tipo copo de pressão, cujo fundo foi preenchido com pequenas bolas de vidro (bolinhas de gude) até as aves completarem 10 dias, para evitar o afogamento dos pintos. Os comedouros foram então substituídos por comedouros do tipo tubular, semi automáticos, com capacidade para $3 \mathrm{~kg}$ de ração, e os bebedouros por bebedouros automáticos para pintos de frangos de corte, nos quais também se usaram as bolas de vidro durante os primeiros 10 dias, até que as aves tivessem atingido um tamanho adequado. Durante os primeiros 21 dias foi providenciado aquecimento constante através de campânulas elétricas com lâmpada incandescente de 200 watts; a partir dos 10 dias de vida as lâmpadas eram desligadas durante os períodos mais quentes, sempre que as aves começavam a demonstrar desconforto térmico.

As aves foram criadas de 1 a 49 dias em sistema de piso com cama de maravalha, trocada sempre que necessário, de modo a manter as boas condições sanitárias e de conforto. A alimentação e a água foram fornecidas à vontade durante todo o período experimental.

Foram utilizadas quatro rações experimentais, contendo, respectivamente, 20, 22, 24 e $26 \%$ de proteína bruta e $2900 \mathrm{kcal}$ de energia metabolizável, baseadas nas recomendações para as fases de cria, recria e engorda do NRC (1994), sendo mantidos constantes os níveis dos demais nutrientes. A composição percentual e calculada das rações experimentais encontram-se na TABELA 1.

TABELA 1 - COMPOSIÇÃO PERCENTUAL E VALORES CALCULADOS DAS RAÇÕES EXPERIMENTAIS, DE ACORDO COM O NÍVEL DE PROTEÍNA BRUTA.

\begin{tabular}{|c|c|c|c|c|}
\hline \multirow[t]{2}{*}{ Ingredientes (\%) } & \multicolumn{4}{|c|}{ Proteína Bruta (\%) } \\
\hline & 20 & 22 & 24 & 26 \\
\hline Milho moído & 57,95 & 56,90 & 52,06 & 46,96 \\
\hline Farelo de soja & 30,50 & 28,60 & 33,20 & 37,60 \\
\hline Óleo de soja & 1,84 & 0,75 & 1,16 & 1,70 \\
\hline Milho, glúten & 1,30 & 6,20 & 7,00 & 7,95 \\
\hline Fosfato bicálcico & 1,15 & 1,12 & 1,10 & 1,10 \\
\hline Calcário calcítico & 1,14 & 1,16 & 1,14 & 1,10 \\
\hline Inerte & 4,78 & 3,98 & 3,26 & 2,70 \\
\hline Sal (NaCl) & 0,30 & 0,30 & 0,30 & 0,30 \\
\hline Suplemento vitamínico-mineral ${ }^{1}$ & 0,50 & 0,50 & 0,50 & 0,50 \\
\hline DL - Metionina 99\% & 0,18 & 0,12 & 0,08 & 0,04 \\
\hline L-Lisina $78 \%$ & 0,36 & 0,37 & 0,20 & 0,05 \\
\hline Total & 100,00 & 100,00 & 100,00 & 100,00 \\
\hline \multicolumn{5}{|l|}{ Composição calculada } \\
\hline Energia metabolizável (kcal/kg) & 2908 & 2908 & 2904 & 2904 \\
\hline Proteína bruta (\%) & 20,08 & 22,08 & 24,07 & 26,05 \\
\hline Fibra (\%) & 3,02 & 2,93 & 3,15 & 3,36 \\
\hline Gordura (\%) & 4,02 & 3,03 & 3,34 & 3,78 \\
\hline Metionina $99 \%(\%)$ & 92,35 & 92,19 & 91,93 & 91,72 \\
\hline Met + Cistina (\%) & 0,50 & 0,50 & 0,50 & 0,50 \\
\hline L Lisina $78 \%(\%)$ & 0,83 & 0,86 & 0,89 & 0,92 \\
\hline Cálcio (\%) & 1,30 & 1,30 & 1,30 & 1,30 \\
\hline Fósforo disponível (\%) & 0,80 & 0,80 & 0,80 & 0,81 \\
\hline \multirow[t]{2}{*}{ Sódio (\%) } & 0,30 & 0,30 & 0,30 & 0,31 \\
\hline & 0,16 & 0,16 & 0,16 & 0,16 \\
\hline
\end{tabular}

${ }^{1}$ Suplemento vitamínico-mineral Codormix para codornas nas fases de crescimento e produção - Nutremix Premix Rações Ltda. R. Dr. Raul Rocha Medeiros, 1950-A CEP 15910-000, Monte Alto-SP - Brasil. 
Aos 49 dias foram retiradas, aleatoriamente, cinco aves por box para determinação das características de carcaça, num total de 20 aves (repetições) por tratamento. Após uma dieta hídrica de 8 horas as aves foram pesadas e identificadas individualmente com etiqueta plástica no pé esquerdo, antes de se proceder à degola completa com tesoura, entre os ossos occipital e atlas. Foram sangradas por dois minutos em cone apropriado ao abate de codornas e em seguida escaldadas em escaldadeira elétrica, regulada a uma temperatura de 53 a $55^{\circ} \mathrm{C}$, por 20 a 40 segundos. As aves foram depenadas mecanicamente por 20 segundos, após o que foram levadas para a calha de evisceração, onde foram lavadas e evisceradas através de corte dorsal realizado com tesoura, partindo da cloaca até ao pescoço. Foram registrados os pesos individuais após a evisceração (carcaça eviscerada, desprovida de pés e cabeça), e os respectivos pesos de vísceras comestíveis (fígado, coração e moela) e não comestíveis. Teve-se o cuidado de não fazer lavagens após a abertura das carcaças para evitar adulteração dos pesos por absorção de água. Uma vez concluídas todas as pesagens, as carcaças foram novamente lavadas e resfriadas em água com gelo picado por cinco minutos, sendo então penduradas em ganchos para gotejar, após o que foram novamente pesadas, para se determinar o rendimento pós resfriamento e o percentual de absorção de água no processo de resfriamento. Todos os rendimentos e a absorção de água foram calculados em relação ao peso vivo $[\%$ Rend. carcaça ou parte $=($ Peso da carcaça ou parte x 100) / Peso vivo]. O percentual de absorção de água foi calculado como: \% Absorção de água = [(Peso pós resfriamento - Peso de carcaça) x 100] / Peso vivo.

Os dados de desempenho e de rendimentos de carcaça foram submetidos à análise de variância pelo procedimento GLM do programa SAS (1989), para delineamento inteiramente casualizado com esquema fatorial de 2 sexos $x 4$ níveis protéicos, com 20 repetições, sendo as médias contrastadas pelo teste de Tukey.

\section{Resultados e Discussão}

Os resultados de características de carcaça ao abate aos 49 dias de idade estão apresentados na TABELA 2. Houve interação $(p<0,05)$ para o rendimento de vísceras comestíveis; para as demais características estudadas, houve apenas efeito de sexo.

TABELA 2 - CARACTERÍSTICAS DE CARCAÇA DE CODORNAS DE CORTE, DE AMBOS OS SEXOS, ALIMENTADAS COM QUATRO NÍVEIS DE PROTEÍNA BRUTA, ABATIDAS AOS 49 DIAS.

\begin{tabular}{|c|c|c|c|c|c|}
\hline \multirow[b]{2}{*}{ Característica } & \multicolumn{4}{|c|}{ Nível de proteína bruta (\%) } & \multirow[b]{2}{*}{ Média } \\
\hline & 20 & 22 & 24 & 26 & \\
\hline \multicolumn{6}{|l|}{ Peso Vivo (g) } \\
\hline Macho & 176,1 & 175,2 & 179,2 & 184,6 & $178,8^{b}$ \\
\hline Fêmea & 230,4 & 224,9 & 225,2 & 220,6 & $225,3^{a}$ \\
\hline Média & 203,3 & 200,1 & 202,2 & 202,6 & \\
\hline \multicolumn{6}{|l|}{ Peso de Carcaça (g) } \\
\hline Macho & 130,2 & 129,9 & 132,4 & 135,8 & $132,1^{\mathrm{b}}$ \\
\hline Fêmea & 151,9 & 148,2 & 146,3 & 145,8 & $148,0^{a}$ \\
\hline Média & 141,0 & 139,0 & 139,4 & 148,8 & \\
\hline \multicolumn{6}{|c|}{ Rendimento de carcaça (\%) } \\
\hline Macho & 73,9 & 74,1 & 73,9 & 73,5 & $73,8^{\mathrm{a}}$ \\
\hline Fêmea & 65,8 & 66,0 & 65,0 & 66,1 & $65,7^{b}$ \\
\hline Média & 69,9 & 70,1 & 69,4 & 69,8 & \\
\hline \multicolumn{6}{|c|}{ Rendimento resfriado (\%) } \\
\hline Macho & 75,4 & 75,2 & 73,3 & 76,3 & $75,5^{\mathrm{a}}$ \\
\hline Fêmea & 68,2 & 68,3 & 67,0 & 68,5 & $68,0^{b}$ \\
\hline Média - Mean & 71,8 & 71,7 & 71,2 & 72,4 & \\
\hline \multicolumn{6}{|c|}{$\begin{array}{l}\text { RVC (g) - Rendimento de vísceras } \\
\text { comestíveis }\end{array}$} \\
\hline Macho & 3,4 & $3,5^{\mathrm{b}}$ & 3,7 & 3,4 & 3,5 \\
\hline Fêmea & $3,7^{A B}$ & $4,2^{\mathrm{A} ; \mathrm{a}}$ & $3,5^{\mathrm{B}}$ & $3,7^{A B}$ & 3,8 \\
\hline Média & 3,54 & 3,88 & 3,61 & 3,54 & \\
\hline \multicolumn{6}{|c|}{$\begin{array}{l}\text { RVNC (g) - Rendimento de } \\
\text { vísceras não-comestíveis }\end{array}$} \\
\hline Macho & 3,5 & 3,5 & 3,8 & 3,8 & $3,7^{b}$ \\
\hline Fêmea & 4,7 & 5,0 & 4,6 & 4,3 & $4,6^{\mathrm{a}}$ \\
\hline Média & 4,1 & 4,2 & 4,2 & 4,1 & \\
\hline
\end{tabular}


Avaliação do rendimento de carcaça de codornas para corte alimentadas com dietas com diferentes níveis protéicos

As fêmeas apresentaram um peso vivo de cerca de $26 \%$ maior do que os machos $(p<0,05)$. Contudo esta superioridade caiu para apenas $12 \%$ ao se considerar o peso da carcaça, e inverteu-se ao se considerar tanto o rendimento da carcaça como o rendimento resfriado, uma vez que os rendimentos dos machos foram superiores $(p<0,05)$. Este comportamento das variáveis peso e rendimento é bem documentado e é devido ao maior peso do trato reprodutivo e maior deposição de gordura das fêmeas (CARON et al., 1990; OGUZ et al., 1996; RAJINI e NARAHARI, 1998), o que no presente trabalho se traduziu no maior peso de vísceras não comestíveis observado nas fêmeas. Embora OGUZ et al. (1996) e TABOADA et al. (1998) citem que as fêmeas apresentam fígado mais pesado do que os machos após a maturidade sexual, neste trabalho foi observada superioridade das fêmeas em relação aos machos para rendimento de vísceras comestíveis apenas no nível de $22 \%$ de PB. Esta observação, em conjunto com a superioridade constatada das fêmeas alimentadas com o nível de 22 $\%$ de $\mathrm{PB}$ em relação às que receberam $24 \%$, caracterizou a interação sexo x nível protéico. Contudo, este rendimento superior não pode ser considerado uma vantagem, pois, por se tratar de aves muito pequenas, 0 diminuto tamanho das vísceras consideradas comestíveis faz com que o seu aproveitamento para a alimentação humana não seja ainda compensador. Por outro lado, a diferença observada não foi suficiente para causar diferença no rendimento de carcaça. Não houve diferença $(p>0,05)$ de rendimento de vísceras comestíveis dentro de machos para qualquer nível protéico, nem dentro de fêmeas para os níveis 20, 22 e $26 \%$ nem entre 20,24 e $26 \%$ de PB.

A absorção de água pela carcaça durante o processo de resfriamento por imersão em água com gelo picado não sofreu influência de qualquer dos fatores analisados, razão pela qual os seus resultados não foram incluídos na TABELA 2. Em média observou-se uma absorção de 2,2\% de água, independentemente de sexo ou nível protéico.

\section{Conclusões}

Os níveis protéicos estudados não apresentaram efeito significativo sobre as características de carcaça consideradas. O sexo exerceu um forte efeito sobre a maioria das características, sendo geralmente as fêmeas superiores. Os machos apresentaram melhores resultados de rendimentos de carcaça resfriados e vísceras não comestíveis.

\section{Referências}

CARON, N.; MINVIELLE, F.; DESMARAIS, M.; POSTE, L.M. Mass selection for 45-day body weight in japanese quail: selection response, carcass composition, cooking properties, and sensory characteristics. Poultry Science, Champaign, v. 69, n. 7, p. 1037-1045, 1990.
DARDEN, J. R.; MARKS, H. L. Divergent selection for growth in japanese quail under split and complete nutritional environments. 2. Water and feed intake patterns and abdominal fat and carcass lipid characteristics. Poultry Science, Champaign, v. 67, p. 1111-1122, 1988.

MARKS, H. L. The influence of dietary protein level on body weight of japanese quail lines selected under highand low-protein diets. Poultry Science, Champaign, v. 72, n. 6, p. 1012-1017, 1993.

NATIONAL RESEARCH COUNCIL - NRC. Nutrient requirements of poultry. 9. Ed. Washington: Natl. Acad. Press, 1994. 156p.

OGUZ, I.; ALTAN, O.; KIRKPINAR, F.; SETTAR, P. Body weights, carcass characteristics, organ weights, abdominal fat and lipid content of liver and carcass on two lines of japanese quail (Coturnix coturnix japonica), unselected and selected for four week body weight. British Poultry Science, Edinburg, v. 37, n. 3, p. 579-588, 1996.

OLIVEIRA, E.G.; ALMEIDA, M.I.M.; MENDES, A.A.; VEIGA, N.; DIAS, K. Desempenho produtivo de codornas para corte de ambos os sexos alimentadas com dietas com quatro níveis protéicos. Archives of Veterinary Science. Curitiba. v. 7, n. 2, p. $75-80$, 2002.

OLIVEIRA, N. T. E.; SILVA, M.A.; SOARES, R.T.; FONSECA, J.B.; THIEBAUT, J.T. Exigências de energia e proteína para codornas japonesas machos criadas para a produção de carne. In: REUNIÃO ANUAL DA SBZ, 37., 2000, Viçosa. Anais...Viçosa, 2000.

PANDA, B.; SHRIVASTAV, A. K. Protein requirement of starter quail. In: WORLD'S POULTRY CONGRESS, 16., 1978, Rio de Janeiro. Proceedings... Rio de Janeiro, 1978. p.1347.

RAJINI, R. A.; NARAHARI, D. Dietary energy and protein requirements od growing japanese quails in the tropics. Indian Journal of Animal Sciences, New Delhi, v. 68, n. 10, p. 1082-1086, 1998.

STATISTICAL ANALYSIS SYSTEM - SAS. Language and procedures. 1 ed., version 6 . Cary: SAS Institute, 1989. 638p.

SHRIVASTAV, A. K.; PANDA, B. A review of quail nutrition research in India. World's Poultry Science Journal, Oxford, v. 55, n. 3, p. 73-81, 1999.

TABOADA, P. Efectos del sexo sobre los rendimientos en la codorniz japonesa (Coturnix coturnix japonica) y la composición química de su carne. Revista Cubana de Ciencia Avícola, Havana, v. 22, p. 19-24, 1998.

Recebido para publicação:

$18 / 11 / 2005$

Aprovado:

03/03/2006 